\title{
Virginia Loh
}

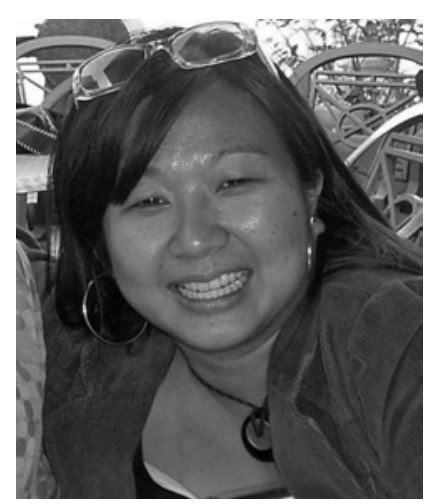

\section{Quantity and Quality:}

The Need for Culturally Authentic Trade Books in Asian-American Young Adult Literature

I walked into Borders bookstore to buy a birthday present for a friend of mine who is also a public school teacher. I wanted to purchase some AsianAmerican children's trade books for her classroom library. To my dismay, this huge bookseller was limited in its supply of books representing the AsianAmerican experience. Outside of the recent Newberyaward winner, Kira-Kira (Kadohata, 2004), AsianAmerican children's literature was not visible or easily available. I scoured the shelves before soliciting help from a salesperson who pointed out a handful of folktales and a couple of books about the internment of Japanese-Americans. There were an even smaller number of books representing the contemporary experiences of Asian-Americans. Adding insult to injury, the salesperson shared with me how much she loved The Five Chinese Brothers (Bishop \& Wiese, 1938), a book that many consider to be an affront to Asian-Americans and which has been deemed by scholars to be racist and inauthentic (Cai 1994).

This incident clearly illustrates an important point about Asian-American trade books today. In spite of the fact that there are more than 12 million AsianAmericans in this country, only a small percentage of the children's trade books published focus on this group. For example, Lee (n.d.) of Lee \& Low Books stated that only $1.5 \%$ of all children's books published in 1997 were about Asians and/or Asian-Americans and Bucher \& Manning (2006) reported that out of 5000 books published in the year 2002, only 91 were by and about Asian-Americans (39). The lack of books focusing on this group presents particular disadvantages in the classroom setting. Because few titles exist, children gain little exposure to Asian-Americans from the books they read in their classrooms. In addition, teachers may lack awareness of whether or not AsianAmericans are portrayed accurately in the books they choose. As a result, students may be denied the opportunity to see into this culture through books; thus, they are denied windows into other cultures. Furthermore, children who are themselves AsianAmerican are denied the opportunity to see themselves mirrored in books.

\section{Lost in the Literature: A Paucity in the Classroom of YAL by, for and about Asian-Americans}

Research tells us that using multicultural children's literature is effective and beneficial (Banks, 2003; Cai, 2002; Bishop, 1992; Lindgren, 1992). Such literature can play an important role in classroom instruction. It provides reading materials and serves as springboards for critical thinking. These trade books supply students with images, ideas and models. In the absence of, or preferably in conjunction with, real-life role models, books can be a powerful tool for promoting cultural understanding. Cai (2002) suggests that multicultural literature is a means of achieving the goals of "diversity and equity in education" (13). He suggests that reading about diverse perspectives enhances multicultural awareness which enables us to recognize things like power and privilege, which may otherwise be invisible to some people. Bishop (1994) contends that multicultural literature is a "vehicle for socialization and change" (43). Scholars and research- 
ers advocate for multicultural children's trade books; but, questions remain about the extent to which teachers are actively selecting and using these books in their classroom practice.

We know that students disengage from education when they see little congruence between home and school (Montecinos, 1994). We also know that teachers play a powerful role in shaping the learning environment, which includes the selection and employment of trade books. Bishop (1992) states, “. . .

the book choices teachers and others make have potential consequences for children. If literature is a mirror that reflects human life, then all children who read or are read to need to see themselves reflected as part of humanity. If they are not, or if their reflections are distorted and ridiculous, there is the danger that they will absorb negative messages about themselves and people like them" (43). In spite of such research supporting a multicultural approach-an approach that nurtures and favors the representation of heritage languages and cultures-many classroom teachers continue to teach from a one dimensional perspective, inadvertently overlooking the voices of marginalized groups and/or people of color.

There appears to be a disconnect between what we know and what we practice in the classrooms in terms of multicultural children's literature. We know that pedagogy based on mainstream American values "will, of course, continue to privilege those who feel most at home in the classroom" (Finders 1997 119). According to Heath (1983), common classroom practices support white, middle-class values; as a result, students who do not fit this mold often feel disconnected. In order to better serve our students, we need to bridge what we know with what we do in the classrooms. One solution could be to select and employ high-quality, authentic literature, especially multicultural children's literature. All students will benefit from learning about multiple perspectives. Practitioners have a great deal of power in regard to the selection and use of multicultural literature.

\section{Key Constructs and Terminology}

Because this article may involve constructs and terminology that may be loosely defined and employed, it is sensible at this point to define the following terms (listed in alphabetical order and written in bold type):

1. Asian-American: Encompassing diverse groups of people differing in culture, language, and belief systems, an "Asian-American" is a U.S. citizen or resident with origins in the Far East, Southeast Asia, Indian subcontinent or the Pacific Islands which may include (but is not limited to) those from the following ethnic heritages: Cambodian, Chinese, East Indian, Filipino, Guamanian, Hawaiian, Hmong, Indonesian, Japanese, Korean, Laotian, Samoan, and Vietnamese (Pang, 1995; U.S. Census Bureau, 2000).

2. Children's Literature: This is a blanket term that often refers to board books, picture books, middle grade books and young adult books. These are books written for and about children and young adults (Galda \& Callinan, 2002). They are categorized as narratives (fiction) and nonnarratives (nonfiction). They include (but are not limited to) the following genres: poetry and verse, folklore, fantasy, science fiction, realistic fiction, historical fiction, and biographies.

3. Contemporary Realistic Fiction: This is a genre, or category, of literature. These fiction stories or problem novels use contemporary, or current, plots, themes, settings, and characters to depict the world as we know it. The storylines are familiar and realistic. They are essentially fictional stories that are "true to life" (Bucher \& Manning 87)

4. Cultural Authenticity: According to Short \& Fox (2003), cultural authenticity generally refers to the degree which a book reflects the "values, facts, and attitudes" (5) of a particular cultural group. Howard (1991) claims that an authentic book is one in which "readers from the culture will know that it is true" (p. 92) and "readers from another culture will feel that it is true" (92). Both Howard (1991) and Karem (2004) also note the importance of reader response in defining authenticity as the reader must accept and believe what is being represented. It is prudent to note that scholars have a difficult time agreeing on an established definition of cultural authenticity (Short \& Fox, 2003).

5. Membership: Membership is usually affiliated with racial, ethnic or cultural backgrounds. Nonmembers, persons who are not of a particular racial, ethnic or cultural background, are also referred to as outsiders; Members are referred to as insiders. In the literature, there is generally more debate concerning nonmembers, who are criticized for not being able to represent the "nuances of day to day living" (Bishop 43) of another culture; whereas, members are assumed to have access and knowledge of cultural codes that allow them to accurately represent themselves.

6. Multicultural children's literature: According to Bishop (1992), multicultural children's literature consists of "literature by and about people who are members of groups considered to be outside the socio-political mainstream of the United States" (39).

7. Perspectives: An ethnic, or insider, perspective is one in which the author and reader clearly know about the particular cultural group represented. In producing culturally authentic literature, Cai (2002) notes the importance of an insider perspective which is needed to truthfully reflect and evaluate "the reality of an ethnic culture" (41). He does suggests that one does not necessarily have to be a member to have an insider perspective. On the other hand, an outsider perspective denotes someone who does not have a "special sense of reality" (Cai 41) meaning he/she is obviously unknowledgeable about and unfamiliar with the lived experiences of that specific culture.

8. Trade Books: These texts are literature-based books that employ authentic and natural language instead of controlled vocabulary and syntax. They are in direct opposition to basal readers or textbooks (NCREL, 2005). 
The use or non-use of multicultural children's literature affects all children. Klein (1998) posits that children of color may not view their color and culture as significant if they only look out into a world of allwhite faces; they need role models and positive representations which may increase their self-esteem and self-development. On the other hand, Anglo-

American children may view themselves to be

\section{Cai (2002) suggests that} multicultural literature is a means of achieving the goals of "diversity and equity in education" (13). He suggests that reading about diverse perspectives enhances multicultural awareness which enables us to recognize things like power and privilege, which may otherwise be invisible to some people. superior due to the lack of exposure. Without any opportunities to observe diverse cultures and heritages, these AngloAmerican children may not be able to understand and respect differences and diversity. In the absence of culturallyauthentic representations, children may be exposed to racist and sexist attitudes, which can be perpetuated by books and other media (Leung, 2003). Over time, such pervasive images can distort their perceptions allowing stereotypes to become reality. In the absence of culturally authentic texts, Asian American students may continue to be stereotyped and neglected. Wills and Mehan note, "Women and people of color must be visible in specific historical events to be visible in history. Furthermore, they must appear as active participants, that is, social actors who made sense of their circumstances and orient their actions to others around them" (8).

In many cases, however, multicultural texts are additions to classroom libraries and not necessarily the foci of classroom practice. For example, the AsianAmerican experience is often relegated to Chinese New Year and/or lessons surrounding the California Gold Rush and transcontinental railroad; such practices may promote tokenism (Banks, 2003). Also, the current practice of using these books for holidays may promote exoticism (Willis-Rivera \& Meeker, 2002) as Asian-Americans are placed outside the common historical narrative (Wills \& Mehan, 1996). Thus, the effective use of multicultural children's literature, via employment of a critical lens, may better equip them to function in a pluralistic society (Leung, 2003).

At the American Educational Research Association's 2004 Annual Conference in San Diego, three recurring themes became prevalent in regards to research on Asian-American student populations. First, despite growing numbers, their existence continues to be nearly invisible. According to the U.S. Census (2002), there are an estimated 12 million Asian-Americans in the United States, or about 4 percent of the total population. In addition, AsianAmericans are one of the fastest growing groups in the nation. Over the last decade there was a 69 percent growth in that population, and their numbers are expected to reach 20 million by 2020 . So, why aren't they better represented in our mainstream culture? If addressed at all, Asian-American issues tend to be brushed under the larger umbrella of multiculturalism and diversity or even, urban education.

Third, Asian-American students are in desperate need of positive role models and advocates, which includes teachers of color. Pang's (1995) research suggests that Asian-Americans have lower levels of self-esteem than their counterparts. For AsianAmerican youth, the consequences of not having role models and positive images to help counter pressures brought on prevailing stereotypes especially the model minority myth may include the following: high suicide attempt rates, low self-esteem, increase in drug and alcohol abuse, increase in promiscuity, etc. (Siu, 1996; Grunbaum, et.al, 2000; Lee, 2003). In reviewing 34 studies of juvenile delinquency among Asian-Pacific Islanders published since 1970, Le (2002) found that Asian/Pacific Islanders are increasing their presence in the juvenile justice system whereas black and white youths are decreasing in their numbers. Le also suggests that contributing factors for gang affiliation and juvenile delinquency among Asian-Pacific Islanders are stresses related to assimilation and posttraumatic war syndrome especially among southeast Asian youth. In addition, Jenkins \& Austin (as cited by Dowd, 1992) assert that books reflecting the diversity 
of the pan-Asian-American experience especially of Southeast Asian refugees and immigrants are lacking; so this particular ethnic group may be at more risk.

\section{Consequences of Under-Representation}

Because Asian-Americans are not adequately and/ or positively represented in the textbooks, literature, and other media images, they may be marginalized. Because of this, children may be denied the opportunity to read and learn about their native heritages. Due to the paucity of Asian-American trade books, children may also lack exposure to positive and realistic portrayals of Asian-Americans in life and in books; as a result, they may rely on gross stereotypes and superficial assumptions when making judgments about people and about themselves. There is evidence suggesting that Asian-Americans feel trapped by stereotypes and prevailing negative images and are thus, often misunderstood and/or ignored (Lee, 2003). These conceptions may even affect the adult lives of Asian-Americans. For example, Liang, Lee, and Ting (2002), in their study of Asian-Americans and glass ceilings, claim that as a result of Asian-Americans being stereotyped as passive, unassertive and docile, they are perceived to be lacking in leadership skills and thus, are denied positions of power.

Such positioning and mis-representation may result in other unfavorable consequences. The following have been associated with the young AsianAmerican community: high suicide attempt rates, low self-esteem, increase in drug and alcohol abuse, increase in promiscuity, high participation in gangs, etc. (Siu, 1996; Grunbaum, et.al, 2000; Lee, 2003). This may or may not be due to a lack of role models and positive images. However, the research does suggest the importance of role models especially for students of color (Keith \& Keith, 1993; Finders, 1997; Sheets, 2001; Applied Research Center, 2002; Bell, 2002; Baldwin, 2004; Montecinos, 2004). In order to give the Asian-American experience agency and power and to re-position Asian-Americans inside the common American narrative (Wills \& Mehan, 1996), teachers and students need access to culturallyauthentic texts.

Thus, increasing the quantity and quality of Asian-American children's literature may help to increase their visibility, counter prevailing stereotypes and provide positive images and role models. Accord- ing to Bishop (1992), multicultural literature is a "vehicle for socialization and change." In schools, texts which include literature, textbooks, etc. are used to disseminate knowledge and to produce and reproduce society (Mehan \& Robert, 2001). Unfortunately, the literature suggests that there is a scarcity of culturally-relevant materials (Bishop, 1992; Lee, n.d.; Wills \& Mehan, 1996; Yeh, Chen, Kwang, Chiang, Wang, \& Pu-Folkes, 2002).

Given this scarcity, students will continue to lack the necessary information to understand diverse voices and thus, they may fail to bring marginalized groups of people into the "common narrative" (Wills \& Mehan). Therefore, there is a real need to increase the quantity and quality of high-quality, culturallyauthentic Asian-Americans
If addressed at all, AsianAmerican issues tend to

\section{be brushed under the} larger umbrella of multiculturalism and diversity or even urban education. trade books in classrooms. Lee (2003) writes, "students need a truly multicultural curriculum that challenges the idea that Asianness and Americanness are mutually exclusive categories" (48).

It is important to note that there is a difference between Asians and Asian-Americans. For example, a Chinese person growing up in China will have a significantly different experience from a Chinese person growing up in America. Thus, my definition of this genre encompasses those of an Asian ethnic background who were born or who are residing in the United States of America. This is inclusive of immigration and emigration experiences. Books which feature an Asian-American traveling and/or living abroad are included. It is also important to note that not all books featuring Asian-Americans can be considered AsianAmerican literature (Bishop, 1982) as some books will have Asian-American characters but ignore the AsianAmerican experience.

\section{"Asian-American." What Does It Mean? Understanding the Diversity}

It is important to address the term "AsianAmerican," which is complex and diverse. Encompassing diverse groups of people differing in culture, 
The term "Asian-American" includes (but is not limited

to) those from the follow-

ing ethnic heritages: Cam-

bodian, Chinese, East

Indian, Filipino, Guama-

nian, Hawailian, Hmong,

Indonesian, Japanese,

Korean, Laotian, Samoan,

and Vietnamese (Pang,

1995). language, and belief

systems, the term "Asian-

American" includes (but is

not limited to) those from

the following ethnic

heritages: Cambodian,

Chinese, East Indian,

Filipino, Guamanian,

Hawaiian, Hmong,

Indonesian, Japanese, Korean, Laotian, Samoan, and Vietnamese (Pang, 1995). According to the

U.S. Census Bureau

(2000), an Asian-American

is "a U.S. citizen or

resident having origins in

any of the original peoples

of the Far East, Southeast

Asia, the Indian subconti-

nent, or the Pacific Islands.”

This diversity and

richness of the Asian-American experience may be a leading factor in its failure to be adequately represented in the publishing world as there is much confusion and inter-ethnic strife. When examining the inter-ethnic politics of these groups, one will find that there are prejudices and dissent among Asian-Americans. For example, historically, there is animosity between Koreans and Japanese because of the Japanese occupation of Korea. In addition, Far East Asians tend to have prejudices toward Southeast Asians as they consider Southeast Asians to be from a third world mentality. To further complicate the matter, there are also differences between American-born and immigrant Asians as well

as differences between generations of Asian-Americans.

However, the Asian-American identity is more similar than different. In addition to sharing similar physical traits, Asian-Americans share the common experience of assimilating and acculturating into a dominant Anglo-American, middle-class culture. Aoki (1992) stresses the importance of not over-generalizing differences between cultural groups.

\section{Cultural Authenticity}

Cultural authenticity looks at how accurately people of color are represented and/or portrayed in the text specific to their culture (Mikkelson, 1998; Higgins, 2002). Because cultural authenticity is influenced by power and perspective, a concrete definition is hard to operationalize. Different cultural groups have different criteria for cultural authenticity (Higgins, 2002). Whether or not a book is culturally authentic is often the subject of analytical discussions; however, what exactly is cultural authenticity is not clearly defined. Karem (2004) contends, "Reviewers from different aesthetic and ideological extremes have argued about what was authentic about a text or culture in their historical moment, but few of them have eschewed authenticity as a category of critical judgment" (6). The scarce use of cultural authenticity as a judgment criteria may be a result of an ambiguous understanding of cultural authenticity. For the most part, an authentic work illustrates one's intimate familiarity with the nuances of a culture and that this may or may not be a result of one's ethnicity (Yokota, 1993).

Much of the controversy that surrounds cultural authenticity deals with authorship. Nonmembers, usually Anglo-Americans writing about cultures and people outside of their cultural background are subject to the most criticism (Bishop, 1992). The general assumption, which is not accepted by all scholars, is that nonmembers, also referred to as outsiders, are unable to represent the "nuances of day to day living" (43) of another culture. Some scholars (Aoki, 1992; Mikkleson, 1998; Slapin \& Seale, 1992) maintain that authentic books are only those written by members, also referred to as insiders, as they have access and knowledge of cultural codes that allow them to accurately represent themselves. However, other scholars (Barrera, Liguori \& Salas, 1992; Howard, 1991) acknowledge nonmembers who have researched and/or immersed themselves in another culture as being able to produce authentic books. In this sense, a culturally-authentic book is one in which the details truthfully represent the culture as determined by a member of that culture.

\section{The History of Asian-American Children's YAL}

Children's literature is playing a more important role in the educational and family trade books market as evidenced by its increasing numbers. In 1940, only 984 books were published for children (Mendoza \& 
Reese, 2001). Today, the children's book market publishes over 5000 books a year (Sautter, 2005), which suggests that there is a growing awareness of the power of these books. The two main influences for this increase are its use as a vehicle for helping children understand and cope with complex decisions and the renewed educational focus on authentic stories for literacy and language development (Ayala, 1999). Because children's literature is perceived to have an influential role in the socialization of children, representations or lack of representations of women and people of color in these books have come under closer scrutiny (Boutte, 2002). Unfortunately, there still remains an imbalance in the types of books being published and consumed.

Compared to the number of children's books published each year, multicultural trade books, although increasing, still only make up a small percentage of the market. For instance, out of 5000 books published in the year 2002, only 91 were by and about Asian-Americans (Bucher \& Manning, 2006). In addition, the number of multicultural books published is still not commensurate with current demographics (Higgins, 2002; Nilsson, 2005). For example, even though there are more than 12 million Asian-Americans in this country, only a small percentage of the children's trade books published focus on this group; Lee (n.d.) of Lee \& Low Books stated that only $1.5 \%$ of all children's books published in 1997 were about Asians and/or Asian-Americans. Furthermore, of the few that are published, only a small percentage could be considered to be culturally authentic (Barrera, Liguori \& Salas, 1992; Sims, 1982; Bishop, 1992; Higgins, 2002). Other studies conducted by scholars such as Cobb and Reimer (as cited by Klein, 1998) have produced the same results: (1) the number of multicultural children's trade books are not commensurate with the demographics and (2) children's trade books have evidence of stereotyping (Ayala, 1999; Nilsson, 2005). In addition, Pace's 1992 study (as cited by Boutte, 2002) noted that high school literature anthologies were not ethnically diverse. These studies support the notion that there are problems with representation, quantity and quality.

Despite the increase in books written specifically for ethnic audiences and by ethnic writers, AngloAmerican perspectives still controlled and continue to control much of the publishing markets. As a result, people of color diverged from the mainstream and formed small presses and established writing contests and awards for ethnic writers and illustrators (Lindgren, 1991). For example, Asian-American children's literature began to emerge from such writing contests and publishing houses such as Lee \& Low (Lindgren, 1991). The majority of multicultural children's books written from ethnic frames of reference continue to be from small, independent presses

(Mendoza \& Reese, 2001). First, most AsianAmerican children's trade books focus on the Chinese-American or Japanese-American experience; however, the Korean-American and VietnameseAmerican experiences are on the rise. This means that other Asian ethnicities like Hmong, Laotion, etc. are not well-represented. Second, there are three popular story themes prevalent in this genre: (1) stories about the U.S. immigration experience as a result of oppression in native countries, (2) stories about the prejudices newcomers face, and (3) stories about coming to terms with one's cultural heritage while adjusting or assimilating to an American lifestyle. Third, there is a need for more contemporary realistic fiction trade books as there exists significantly more Asian folklore. Fourth, most of the historical fiction addresses the Japanese internment experience. Fifth, most nonfiction books are about the lives of recent immigrants. From these trends, we ascertain that there needs to be a more substantial and rich body of literature reflective of the diverse experiences of being Asian-American.

Despite this, it is encouraging that Asian-American children's literature continues to grow. The research on Asian-American children's literature is also increasing albeit disproportionately. Such research is important in that it allows us to better assess the status of this genre and advocate for appropriate changes. For example, Louie (1993) examined eight young adult novels with Asian-American characters published between 1987 and 1992. She found that these books projected typical stereotypes with weak and indecisive characters such as the "Suzy Wong" 
and "model minority" caricatures.

She also found that three characters

rejected their Asian-American heritages and that only three stories contained mature and realistic characters. Louie felt that there weren't enough Asian-American stories and too few that contained male characters. Klein's study (1998) provides another example of the problem with representation. Over a period of 31 years, Klein (1998) studied the recommended reading lists for high school students put out by the National Council of Teachers of English. She found that Asian-Americans were the only ethnic group to decrease in percentage of annotations from 1964 to 1995 . They were also the only ethnic group to still have the majority of the settings take place in another country and to not have their characters increase in importance. Although their roles were less stereotypical, they weren't necessarily more varied. The most common roles for AsianAmericans were "coming of age," "warrior," “civilian in war," and "professional." The roles that decreased were "leader," "culture," "romance," and "selfsufficient” (27). The most common story lines were those of immigration and assimilation. As a result of studies such as these, authors, teachers and publishing houses may be influenced to produce higher quality and more authentic literature.

Even though representation remains problematic, the quality of Asian-American children's literature has improved over time. In Harada's (1995) study of the portrayal of Asian-Americans in picture books, she found that $90 \%$ of the books had positive and nonstereotypical portrayals and $80 \%$ of the books had proactive characters. Harada's main criticism was that only five main groups are represented in the literature: Chinese, Japanese, Koreans, Filipinos and Vietnamese. Similarly, a study conducted by Pankratz (as cited by Klein, 1998) also showed how there have been positive changes over time. In 1980, Asian-Americans were mainly depicted as impoverished; whereas, in 1990, $25 \%$ of them were of average wealth and $75 \%$ were impoverished. She also found that in 1980, no Asian-Americans were depicted as main characters; in 1990, 66.6\% played major roles and $33.3 \%$ held minor roles. Klein (1998) also cites another study examining the percentage of reference books with multicultural topics. Asian-Americans at first had no representation and then by volume 30 , were listed $0.3 \%$. This is good but it's not good enough; Asian-Americans are still misrepresented and underrepresented in trade books.

As evidenced by these studies, the 1990s saw an emergence of critical research and literature examining children's literature for bias, stereotyping, etc. (Mendoza \& Reese, 2001). They used primary sources for historical and cultural information, raising issues of accuracy and authenticity, questioning perspectives and even the motives of Anglo-American writers writing about people of color. However, these studies are mainly published in less widely-known and prestigious journals and non-mainstream presses. Given that recognition and availability are the main motives for buying and using books, awards and reviews are also significant factors in sales and dissemination. Mendoza and Reese (2001) contend that reviewers and award committees rarely consider issues of cultural and historical accuracy and authenticity. In addition, Dowd (1992) contends that the voices of Asian-American authors and artists are minimized by mainstream presses; thus, smaller presses more often than not publish multicultural books. As such, these smaller presses do not have the marketing capacities and recognition as the larger presses.

\section{Representations of Asian-Americans: Problematizing the Status Quo}

As aforementioned, Klein (1998) found that the percentage of multicultural trade books on the recommended reading lists devised by the National 
Council of Teachers of English has increased over a period of 31 years; however, she noted that the percentage of Asian-American trade books did not increase during this period. In addition, for all groups except for Asian-Americans, multicultural characters have increased in importance meaning Asian-American characters have not played significant roles. A number of scholars observed that the Asian-American identity is often overlooked by dominant society as evidenced by its lack of representation in the mainstream literature (Cai, 2002). Aoki (1992) writes, "Asian Pacific American people have been separated from Asia and the Pacific by geography, culture, and history for more than seven generations. We have more than 150 years of history in America, yet where are we in the literature?" (112-113). With the growing Asian-American student population, there is a real necessity for books that represent this culture. It is important for all students and especially, AsianAmerican students, to be exposed to positive, nonstereotypical images of Asian-Americans. Furthermore, Asian-American students need to feel validation and pride for the contributions and achievements of other Asian-Americans.

Why do Asian-Americans continue to be lost in the literature and school curriculums? Asian-Americans have experiences, people and histories that extend beyond Chinese New Year. The lack of adequate representations of Asian-Americans is detrimental to all of our students in that: (1) the proliferation of degrading stereotypes serve to dehumanize the history, lives and experiences of Asian-Americans which fosters racism and prejudice; and (2) the absence or silencing of insider perspectives marginalizes Asian-Americans which encourages cultural separatism (Willis-Rivera \& Meeker, 2002). In this marginalization of Asian-Americans and other minorities from popular discourse, we may continue to replicate current systems of white, patriarchal hegemonic practices.

Willis-Rivera and Meeker (2002) posit that multicultural children's literature is written for "white” audiences: "These stories (of the literature in general) can often only be read 'correctly' from a standpoint of whiteness” (272). As a result, the white frame of reference is not only privileged but controls the position of the people of color in the text. As such, people of color are often acted upon instead of being able to control their own behaviors. Anglo-Americans are more often than not the implicit intended audience of these books. This has implications for how diversity is addressed and should be taught to students. These authors argue against framing multicultural literature in a way that positions readers of color as "other" or "exotic." Such readings may give Anglo-American readers the appearance of diversity by allowing them to lessen their guilt; in other words, since they are reading these books about people of color, they can feel less guilty about white privilege. In order to counteract this, teachers need to explicitly discuss white privileging in these trade books.

Historically, Anglo-Americans have had greater access to mainstream audiences as evidenced by book sales and book quantities. The recruitment of authors of color is important because authors of color have experienced various degrees of institutionalized racism. They do not have as much access to the publishing world as Anglo-Americans do. Bishop (1984) points out that the politics behind publishing deems what is
Aoki (1992) writes, “Asian Pacific American people have been separated from Asia and the Pacific by geography, culture, and history for more than seven generations. We have more than 150 years of history in America, yet where are we in the literature?"' (112-113). accepted and what is not accepted. She notes the importance of the intended audience. Books about diversity told from an Anglo-

American perspective were more likely to get published. Thus, for whom books are intended matters in that reception determines production.

It is not surprising that popular images in the media and literature perpetuate stereotypes. In regard to Asian-Americans, there are two dominating images, both of which serve to denigrate the AsianAmerican identity. Lee's (2003) study contended that AsianAmerican students are impacted greatly by the stereotypes of the 
perpetual foreigner and the model minority, both of which are reinforced by schools and reflected in the literature. As school curriculums and libraries exclude the Asian-American experience, AsianAmericans may adopt and internalize prevailing notions which can negatively affect their academic performance and their socialaffective development. Lee (2003) found that even American-born Asian-Americans consider AngloAmericans to be the only authentic Americans thus, discounting their own identity affiliation. Believing themselves to be "foreign," they may be less likely to participate in class, downplay physical traits by getting colored contacts, dying their hair or rejecting their names, languages and even other AsianAmerican peers.

The model minority theory, according to Lee (2003), has far worse implications than that of the perpetual foreigner. Seemingly positive, it is often not considered to be racist. Lee (2003) claims that the model minority theory denies that Asian-Americans continue to struggle against institutionalized racism and other barriers. As a result, they are denied access to programs and policies that encourage and support minorities. The myth also suggests that other minorities are not "model," which is detrimental to other groups of color (Lee, 2003). Asian-Americans do not have strong political advocacy groups like AfricanAmericans and Hispanic-Americans. Over the past decade, both of these groups have established a body of literature that allows for more complex and multifaceted representations.

The Asian-American children's trade books that are currently being used in the classrooms consist mostly of folktales and those with a Chinese New Year theme (Cai, 1994). In any study of Asian-Americans, it is important to explore significant elements of the heritage culture. Since folktales are passed down orally, they still remain a vital part of the Asian-American experience. For example, Young's (1995) Cat and Rat: The Legend of the Chinese Zodiac tells the story of how the animals were chosen to be part of the zodiac, a belief system to which many Asian-Americans still adhere. Interestingly, Reimer (1992) claims that children's literature did not exist in Asian countries until the $19^{\text {th }}$ century. Therefore, having these stories in written form secures its preservation. However, when using folktales in multicultural lessons, there is a caveat. Cai (1994) asserts that using an overwhelming proportion of folktales can be misleading as students are distanced from the contemporary realities of the AsianAmerican experience and the folktales, may unintentionally reinforce negative stereotypes. Thus, a substantive body of literature featuring the complexities of the Asian-American identity is necessary.

In the absence of such a body of high-quality and culturallyauthentic Asian-American children's literature, Asian-Americans may be held against stereotypes that are not only grossly misinformed but also monolithic. Dowd (1992) notes some of the current mis-representations of Asian-Americans in children's literature. Asian men are often depicted in the following ways: smiling and polite, constantly bowing, proficient in the martial arts, celestial and allknowing, and/or creepy or devious. They are sometimes drawn with squinty eyes and buck-teeth. Asian women, on the other hand, are depicted as: submissive, overbearing, old-fashioned grandmother-types. They are referred to as sexy "China dolls" or sinister "dragon ladies." Such stereotypes contribute to the misconception that Asian-Americans are outside of the common historical narrative (Wills \& Mehan, 1996).

In reviewing the research literature (Cai, 1994; Lowery, 2003; Tse, 1998; and Heller, Cunningham, 
Lee, \& Heller, 2000), there are some obvious characteristics of the current body of Asian-American children's literature. They include, but are not limited to:

- Confucian ethical codes which include filial piety,

- Idea of harmony, spirits, traditions, luck, and horoscopes,

- Brotherhood among family, friends, colleagues, and neighbors leading toward mutual help, communal support, and collective wisdom,

- Importance of honesty, hard work, selflessness, and sacrifice,

- Importance of the arts and education,

- Adjustment and assimilation to a new life encountering feelings of isolation, loneliness, poverty, language barriers, and racial discrimination,

- Need to belong to a desired group and obtain acceptance leading to feelings of ethnic ambivalence and confusion,

- Quest for successes in the new world,

- Depictions of historical and class relations between Asian immigrants and mainstream society,

- Ancestral worship which includes loving, respecting, and honoring the dead,

- Reverence for the elderly,

- Conflicts between tradition and pop or contemporary culture which may result in rebellion against parental and/or cultural constraints.

Many of these characteristics seem to align with what is known about various Asian cultures. As AsianAmericans do share certain cultural values and mores that are tied to an Asian culture, it is important for the literature to reflect these traditions and customs. But it is equally as important for the literature to depict contemporary experiences that speak to being both Asian and American. Again, a substantive body of literature is needed.

\section{Cultural Authenticity and Cultural Membership}

Using Bishop's (1984) definition of a culturallyspecific book, a culturally-authentic Asian-American text describes the realistic experiences of its members and/or outlines relevant historical episodes as seen through the eyes of an Asian-American. Bishop (1984) further claims that such books must detail "the specifics of daily living that will be recognizable to members of the group" (44). In other words, the text must reflect an emic, or insider perspective. Bishop's (1984) research raises the questions as to whether one can produce a "recognizable" text and not be a member?

The research literature addresses insider and outsider perspectives, with debates about whether a person who is not a member of the cultural groups can authentically write about that culture (Bishop, 1992). Writing outside one's gender does not seem to be as controversial as race and ethnicity, which seems to suggest that issues of power and perspective, as exposed by critical literacy, play substantial roles in determining cultural authenticity. Critical theorists believe that members of minority groups tend to not have central control over the production of images of themselves (Morgan, 1997). The largest and most prestigious publishing houses are managed by AngloAmericans who dominate the decision-making process. According to Mendoza and Reese (2001), “. . .

bias and cultural misinformation are present in children's literature in part because people outside the mainstream are not the ones creating the images; members of the dominant culture are creating representations based on their own mistaken assumptions of what the 'others' are like” (33). Thus, insider perspectives are necessary in order to ensure cultural authenticity.

Yin (2000) presupposes that authentic AsianAmerican texts written from an insider perspective are more sensitive to the Asian-American experience. Cai (2002) promotes the importance of an ethnic perspective in that authors must "grasp the perspective of that culture in order to provide culturally authentic literature for the readers ... this perspective is reflected in culturally specific ways of living, believing and behaving" (41). There is also an issue of cultural theft; Thelma Seto, a Japanese-American writer and poet, writes (as cited by Klein, 1998) states, “. . . it is morally wrong for Euro-American writers to 'steal' from other cultures in order to jump on the multicultural bandwagon, unless they have direct, personal experience in the country where that culture originates ..." (4). In addition, Phoebe Yeh, AsianAmerican book editor and author (as cited by Klein, 1998), writes, "We expect all writers to approach their work with scholarship and authenticity. If they are writing in a culture that is not their own, they simply have to work harder to achieve an ethnic voice" (4). As such, I argue that perspective is more important 
than skin color in that the two terms may not necessarily be synonymous as is generally assumed.

Some research suggests that the issue is less about the ethnic identity of the author and more about their research. For example, Linda Sue Park, a member,

provides another example of the importance of In outlining definitions of high quality multicultural literature, rarely is the race of the author identi-

fied, which seems to suggest that skin color may not play a significant role in the quality of the

text. However, one's culture and personal experiences do add to the content and quality of the text.

research in obtaining an insider perspective. Park, winner of the 2002 Newbery Medal, credits her research abilities and not her Korean roots in her authorship of $A$ Single Shard, (Johnson \& Giorgis, 2002/2003). Howard (1991) strongly asserts that one must be of a particular culture in order to write an authentic book reflecting that culture; however, in the same paragraph, she praises the authentic work of Jean Fritz, a nonmember who has written extensively about China. Howard writes, "Jean Fritz is Chinese. If she isn't, she's pretty close. Jean Fritz grew up in China, knows

Chinese people well, and she wrote about herself in China" (93). Howard claims that Fritz's immersion into the culture gave her access to an insider perspective as well as membership into that culture. Gates (as cited in Bishop, 1992) states, "No human culture is inaccessible to someone who makes the effort to understand, to learn, to inhabit another world" (41). Research and access appear to be the keys. Writers need access into cultures to produce cultural authenticity; teachers and students need access to literature in order to practice cultural appreciation and understanding.

In examining what is available, the fact is there are examples of high quality, culturally authentic Asian-American literature that are written by nonmembers and that there are members who write inauthentic literature. For publishers, the question is: What should take precedence: an author's race/ ethnicity or an author's research and scrutiny? Lee (n.d), of Lee \& Low Publishing house, states, "The ethnicity of the authors and artists is an important factor, but by no means do we feel it is a requirement" (14). Skin color, or racial identity does not automatically qualify work as authentic. Both members and nonmembers need to research their topics and immerse themselves in the culture of which they are writing. The objective is to increase the amount of high-quality, culturally-authentic Asian-American children's literature. By invalidating the work of nonmembers, we may be unnecessarily decreasing the number of available resources and subverting the need for high quality books in this genre. The underlying issue is whether or not the ethnicity or race of the author affects the text. In outlining definitions of high quality multicultural literature, rarely is the race of the author identified, which seems to suggest that skin color may not play a significant role in the quality of the text. However, one's culture and personal experiences do add to the content and quality of the text.

Reimer (1992) states that the majority of AsianAmerican literature is not written by Asian-Americans. Ford (as cited by Mosely, 1997) contends that nonmembers write books for other cultures because there aren't enough minority writers. The question that begs to be answered at this point is: Why aren't AsianAmericans writing about Asian-Americans? Allen Say (1991), a popular and well-respected Asian-American author and illustrator, initially did not contribute to the genre of Asian-American literature. He states, "I wanted to shine as a nondenominational artist and be recognized for my abilities and not for my cultural heritage (45)." He goes on to state that he denied his heritage because of his fears of being stereotyped. However, as he became more established, writing and illustrating became a medium for connecting with his cultural roots. In today's diverse world, stereotypes can only be broken if we actively challenge and question them.

Reimer (1992) does note, however, that there has been an increase in Asian-American authors writing about their own assimilation experiences such as Yep's (1991) autobiography, The Lost Garden, and Lord's (1984) semi-autobiographical, fictional account, In the Year of the Boar and Jackie Robinson. Because of the positive influence books can have on the attitudes and self-images of our student populations, Asian-Ameri- 
cans have a social responsibility to share their own stories as well as the stories of other Asian-Americans. Regardless of whether or not an author chooses to write about Asian-Americans, authors have a responsibility to produce culturally authentic texts. Howard (1991) states, "the purpose of authentic multicultural literature is to help liberate us from all the preconceived stereotypical hang-ups that imprison us within narrow boundaries" (91-92). There is a social responsibility tied to cultural authenticity.

To further complicate the matter, cultural authenticity is "conceptually unstable" (Karem 4) in that it is subject to change and interpretation and is constantly being mediated by power and perspective. Karem (2004) writes, “. . . intense political and economic interests determined which aspects of [the work of ethnic writers] would be deemed authentic, not only constraining what they could publish but also shaping how their works were received and interpreted" (3). Mosely (1997) further explicates this issue of reception: Readers tend to trust authors who belong to the same culture as them. How members and nonmembers respond to text is important. To what extent are the responses shaped by ethnic identities? Copenhaver (1999) writes, "It makes sense to us that responses should be shaped by each reader's background, including her cultural background" (p.). Enciso (1994) showed how some readers might resist or reject a text that does not reflect their cultural expectations. Members use their cultural expectations to detect violations and inaccurancies (Galda \& Beach, 2001). Knowing about the readers' background is valuable since it influences their response to their reading.

\section{Models for Assessing Cultural Authenticity}

Willis-Rivera and Meeker (2002) contend that teachers do not include multicultural literature in their classrooms for fear of giving the wrong message. Not being a member of the group, some teachers fear offending others and/or inadvertently selecting and sharing inappropriate books. As a result, classroom libraries may have an absence of culturally-authentic materials or worse, trade books consisting of negative representations. Bishop (1992) writes, "because of the limited quantity of multicultural literature available, there may be a tendency to accept poor literary quality just to have something in the classroom or library" (48). Examining the cultural authenticity of children's texts is important because these texts can serve as powerful tools for change; however, the problem is that teachers do not know how to assess cultural authenticity. Bishop (1992) states, "Feeling a lack of knowledge about cultural groups other than their own, they worry whether they can detect authenticity or its lack" (43).

Without heuristics, teachers may not have the available knowledge to detect cultural authenticity. Mendoza \& Reese (2001) state, "Limited availability of criticism that addresses accuracy, authenticity, and related problems often leads to a major pitfall for teachers seeking multicultural books" (11). They cite the following as pitfalls for teaching multicultural books: (1) the assumption that a book is multicultural and worthwhile if is has diverse people and/or is critically acclaimed, (2) the assumption that a single book about a group can adequately portray that group's experience, (3) the assumption that good quality books can be found in libraries and bookstores as such books are often times not readily available or easily accessible, and (4) teachers may feel overwhelmed by the prospect of finding and evaluating books.

The process of selecting multicultural books can be overwhelming. Left to their own devices, consumers of multicultural children's literature may rely on a lens which has been influenced by their own biased schooling and which may be devoid of insight into their own racial identity development (Mendoza \& Reese, 2001). Mendoza \& Reese (2001) state, "Reliable, in-depth background information about the diverse groups and cultures in the United States is essential to 
evaluating multicultural children's literature" (27). Consumers need to have knowledge of cultural markers, indicators that the story is about a particular culture. The reality is that teachers and parents may not have the time needed to increase their cultural knowledge bases; thus, a reliable tool may be beneficial. Dowd (1992) contends, "The first consideration in critically evaluating a multicultural title is that it should meet the same requirements of any piece of high quality literature" (221). Similarly, Rosenblatt (as cited by DeKay, 1996) also notes how linguistic elements contribute to the quality of literature. Examining cultural authenticity includes literary merit.

1980, the Council on Interracial Children's Books published "Guidelines for Selecting Bias-Free Textbooks and Storybooks" which is most cited for assessing the cultural authenticity of multicultural texts). They offer the following ten guidelines as a starting point in evaluating children's books for racism and sexism (Council, n.d):

1. Check the illustrations.

2. Check the story line.

3. Look at the lifestyles.

4. Weigh the relationships between people.

5. Note the heroes.

6. Consider the effect on a child's self-image.

7. Consider the author's or illustrator's background.

8. Check out the author's perspective.

9. Watch for loaded words.

10. Look at the copyright date. Aoki (1992) also offers a set of criteria established by the Asian American Children's Book Project Committee. It claims that culturally-authentic books:

- Should reflect the realities and ways of AsianAmericans.

- Should transcend stereotypes.

- Should seek to rectify historical distortions and omissions.

- Should avoid the "model minority and "super" minority syndromes which uses the positive experiences of Asian-Americans to denigrate other racial and ethnic minorities.

- Should reflect an awareness of the changing status of women in society.

- Should contain art and photos which accurately reflect the racial diversity of Asian Pacific Americans. Others have continued to create assessment models over the years: Temple, Martinez, Yokota and
Naylor (1998); Sadker, Sadker and Long (1993); Dowd (1992); Pang, Colvin, Tran, and Barba (1992); and Higgins (2002). State departments of public instruction have created evaluative tools, as well, such as The Washington Office of the State Superintendent of Public Instruction (1996), which developed a model for evaluating bias content in instructional materials. They created a list of common stereotypes and alternatives. They indicated the following categories of bias found in text: ethnic, sexual, biased language, omission or exclusion, and perspective

The main caveat seems to be attributing characteristics and traits to an entire group without considering individuals and the multiplicity of culture and ethnicity even though there are consistencies among cultural groups. No one image is enough to create stereotypes; but, pervasive images do which are then reinforced by culture and/or society.

Although these frameworks begin to delve into cultural authenticity, they may generate more questions than answers. For example, if the teacher is asked to determine whether the text reflects the reality of Asian-Americans, how is the teacher to know unless they are an insider and/or familiar with the Asian-American experience? It seems to me that an insider perspective is required to figure out some of these issues. For example, what are "the realities and ways of Asian-Americans"? When evaluating cultural authenticity, a tool needs to be developed that speaks to both members and nonmembers.

Nevertheless, These models or guidelines have been extremely helpful in limiting and even decreasing the offensive stereotypes present in trade books as evidenced in the representations in contemporary books. However, such models are only tools. DeKay (1996) writes, “. . . judgments of esthetic quality or value are not subject to clearly discernible, objective criteria" (8). Boutte (2002) notes that guidelines should be used as such and not as a strict evaluation of books. Consumers must actively employ a critical lens when selecting and using multicultural trade books. Dowd (1992) states the importance of engaging in literature-related activities and in becoming knowledgeable.

\section{What Remains to be Done}

Although these models push for critical investigations of multicultural trade books, they are too broad 
to address the Asian-American experience. There is a need for a reliable and research-based tool that is germane to Asian-American children's literature. Inauthentic books continue to be published and circulated because teachers and other consumers may not have the tools to assess cultural authenticity. If such books continue to be circulated, then the authentic books will continue to go unrecognized. It is also important to note that one authentic book is not enough; we need a substantive collection (Higgins, 2002; Washington Office, 1996).

\section{Interview with Cynthia Kadohata}

Q: Would you describe yourself as a writer of multicultural or AsianAmerican children's trade books?

A: My books are about multicultural characters. I don't know whether I would describe myself that way, though it's accurate. I just think of myself as a writer writing about topics that call to me or that I feel compelled to write about.

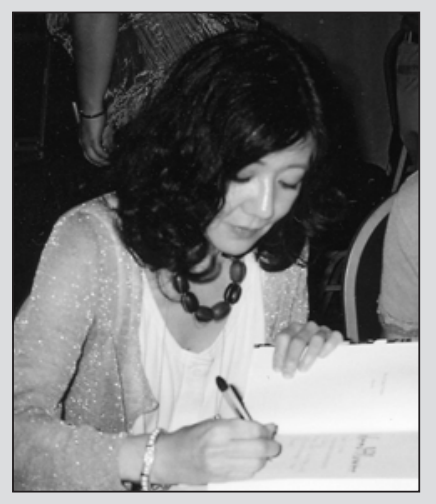

Q: You write about a lot of Asian-American themes. How do you obtain your knowledge base?

A: Mostly from being Asian-American and talking to other Asian-Americans. For Weedflower, I did research and interviewed people. I obtained knowledge through research and through talking to former internees of Poston and through just being of Japanese heritage. I do have to read a lot about the people and places I'm writing about. Yet in the end it all comes down to how well I'm able to understand the characters and their story. Even with all the research and interviews finished, if I can't get in the heads of the characters, the book won't work.

Q: How do you come up with so many authentic details?

A: Some of them are from my life, some of them made-up. Some from research. For Kira-Kira, I was going to write a lot about swamps, so I ended up doing a lot of research about it but then I hardly used any. There's only a small bit about swamps in the book. In Weedflower, I had a long scene about a bus trip. I joined a Greyhound bus yahoo list and asked all these questions about buses during the late thirties and early forties, and I corresponded at length with some of these guys about buses. My editor really liked this section at first but then ended up cutting it.

Q: What do you think about the current representations of Asian-Americans in children's trade books?

A: To tell the truth, I haven't read that many. Since adopting mt son, Sammy, I haven't read much unless it was helpful to something I was writing. For instance, for my upcoming book about Vietnam war dogs, I did re-read The Call of the Wild and Lassie Come-Home because they have prolonged sections without human POVs. I read Animals in Translation and some other books about animals or dogs.

The first book about Asian Americans I remember reading was in college when we were asked to read Maxine Hong Kingston's Woman Warrior, which I think everybody who took an ethnic studies class had to read. They probably still do. We also read Farewell to Manzanar as well. I can't think of another book by an Asian-American writer that I read before. There just weren't any. I mean there might have been some but not very many. Today in children's books, there are a number of people I can think of offhand-Linda Sue Park and An Na come to mind most readily, of course. 
Q: So, how authentically do you think Asian-American customs, traditions, food, etc. are portrayed in these books?

A: I think authors today tend to make a tremendous effort to portray people authentically.

Q: Describe the journey that led you to write and publish Asian-American children's literature. What were some challenges?

A: Just that everyone told me it was an impossibility to write about Asians at all. I think the challenge was that there were so few Asian-American writers to emulate when I started out, but that was in grown-up books. I didn't want to emulate, but to make people believe that we can do it. That was the hard thing: convincing people you can write about Asian Americans. I feel I have to qualify everything I say, because I'm of two minds about all this. Though your home base has to be your ethnicity, one of the challenges is that sometimes you want to write about other things too. Today's writers can write about anything they want, but I think yesterday's writers felt like stories had to based on their ethnicities. I do think that your ethnicity is your home. For me, our being Japanese shaped my family's life profoundly. How can you not have that be the base of who you are and what you are writing about? So even if I write about other things, I still think my ethnicity is one of my homes. It's not my only home but it's certainly one of them.

What drives me crazy is that there are misconceptions about who and what you are if you're a person of color. In one workshop I took, someone said that some of my characters didn't act Japanese enough and I said, "What do you mean?" As I recall, she commented on their diet, and I said that they were traveling on the road and they're not going to be eating sushi on the road. And I had a teacher who once said I couldn't write an entire book with only Japanese as the main characters. He said I had to have them confront whites because ultimately any book about people of Japanese ancestry living in America had to be about what happens when they encounter whites. That also annoyed me.
Q: Why did you choose to write about Asian-Americans?

A: I don't think it was a choice. It was so natural. It was a compulsion.

Q: Do you write about other groups?

A: Well, I'm writing about the Vietnamese indigenous people called the Montagnards, but they're still Asian, though not American. There are other things that I am interested in and I can imagine writing about them. I do have a major Caucasian character in my Vietnam book, though the star of the book is a dog.

Q: What does it mean to write or publish a culturally authentic text?

A: I would think it has to be based on fact, unless you are writing fantasy. And it has to capture the nuances. That may be the hard part.

Q: To what extent, if any, do you think one's ethnic background plays in regard to cultural authenticity?

A: There are a lot of little things about manners or whatever that you learn in a different way when you're Asian. There are little thoughts you have in your head about, whatever, being spit at as I once was by a man yelling out "Bomb the Japanese." You kind of have to experience that to know what it feels like. You have to feel yourself getting hot with anger to understand it. To me, the thing about a white person writing from an Asian point of view is that they don't have that feeling; they don't know that feeling because they haven't experienced it. But I do think they could find that feeling through research and empathy.

Q: So, do you think nonmembers can write about Asian-Americans?

A: Yes, I do. I recently looked at the statistics about people of color writing children's books. The statistics are compiled by the Cooperative Children's Book Center. Asian Americans have made some big strides, while Native Americans and 
African Americans have not. But there are many Caucasians writing about people of color across the board for the statistics up through 2005. I haven't read any of these books but they do make me wonder whether editors are trying hard enough in general to find writers of color. At the same time, I strongly believe that writers should attempt to write about people and subjects they feel compelled to write about. More qualifications! I'm of two minds about it. It bothers me, and yet I do passionately believe in artistic freedom.

Q: Do we have a problem with quantity?

A: Yes, yes, yes. The percentages of books by people of color is well below their percentages in the population. The percentage of Asian authors is low, though the number of books with Asian characters doesn't seem to be low. In other words, if you count books written by Caucasians, then the number of books with Asian characters seems to be commensurate with their percentage in the population-if I understand the statistics correctly.

Q: Do we have a problem with quality?

A: I don't know-I think an editor would know better. And I actually think it's good to have a realistic depiction of history in books, so if a white writer is compelled to write about subject matter that includes people of color, I applaud that. On the other hand, if you find a book and think it's inauthentic, it seems to me that needs to be challenged. That's hard, because you have to keep in mind that there's a lot of diversity within each ethnic group. I don't think one person can speak for an entire ethnic group. There are a lot of thin lines! But I can say absolutely that I wish more children's books BY people of color were published. When-as if the case-a lot more books ABOUT Native Americans are written than BY Native Americans, that strikes me as problematical.
Virginia S. Loh is a doctoral candidate at USD-SDSU, an adjunct professor at USD and NU, an elementary school teacher and a published author. Her debut book is The Jade Dragon (Candlewick Press, October 2006). Her main research interests are Asian-American student populations and multicultural children's literature.

\section{Works Cited}

American Library Association. (2004). Newbery medal and honor books, 1922-present. Retrieved May 5, 2005 from http://www.ala.org/alsc/newbery.html

Aoki, E. (1992). Turning the page: Asian Pacific-American children's literature. In V. J. Harris's (Ed.), Teaching multicultural literature in grade K-8. (pp. 109-135). MA: Christopher-Gordon Publishers.

Applied Research Center. (2002, April). Profiled and punished: How San Diego schools undermine Latino and African American student achievement. Oakland, CA: Author.

Ayala, E.C. (1999). "Poor little things" and "brave little souls": The portrayal of individuals with disabilities in children's literature. Reading Research and Instruction, 39(1), 103-117.

Baldwin, J. (2003). Meeting the challenge of the urban high school. In F. Schutz (Ed.), Annual editions: Education 03/04 (30 ${ }^{\text {th }}$ ed., pp. 142-147). Connecticut: McGraw-Hill/Dushkin. Banks, J.A. (2003). Multicultural education: Characteristics and goals. In J.A. Banks (Ed.), Multicultural education: Issues and perspectives (pp. 3-30). New York: Wiley.
Barrera, R.B., Liguori, O. \& Salas, L. (1992). Ideas a literature can grow on: Key insights for enriching and expanding children's literature about the Mexican-American experience. In Harris, V.J. (Ed.). Teaching Multicultural Literature in Grades K-8. MA: Christopher Gordon Publishers.

Bell, S. (2002). Teachers' perceptions of intergroup conflict in urban schools. Peabody Journal of Education, 77, 59-81.

Bishop, R.S. (2003). Reframing the debate about cultural authenticity. In D.L. Fox \& K.G. Short (Eds.), Stories matter: The complexity of cultural authenticity in children's literature (pp. 25-37). Illinois: National Council of Teachers of English.

Bishop, R. S. (1992). Multicultural literature for children: Making informed choices. In Harris, V.J. (Ed.). Teaching Multicultural Literature in Grades K-8. MA: Christopher Gordon Publishers.

Bucher, K \& Manning, M.L. (2006). Young adult literature: Exploration, evaluation, and appreciation. NJ: Pearson Education, Inc.

Cai, M. (2002). Multicultural literature for children and young adults. USA: Greenwood Press.

Cai, M. (1994). Images of Chinese and Chinese Americans mirrored in picture books. Children's Literature in Education, 25(3), 169-191.

Copenhaver, J.F. (1999, October). The intersections of response and ethnicity: Elementary school students respond to multicultural children's literature. Paper presented at the annual meeting of the South Central Modern Language Association, Memphis, TN. 
Council on Interracial Books for Children. (n.d.). Ten quick ways to analyze children's books for racism and sexism. Retrieved February 27, 2005, from http://www.birchlane.davis.ca.us/ library/10quick.htm

DeKay, S. (1996). Classroom research into the teaching of literature. (ERIC Document Reproduction Service No. ED 399540).

Enciso, P.E. (1994). Cultural identity and response to literature. Language Arts, 71, 524-533.

Finders, M.J. (1997). Just girls: Hidden literacies and life in junior high. NY: Teachers College Press.

Fox D.L., \& Short, K.G. (Eds.). (2003). Stories matter: The complexity of cultural authenticity in children's literature (pp. 25-37). Illinois: National Council of Teachers of English.

Galda, L., Ash, G.E., \& Cullinan, B.E. (2000). Research on children's literature. In Kamil, Mosenthal, Pearson, \& Barr (Eds), Handbook of reading research, Volume III. Retrieved December 6, 2005 from http://www.readingonline.org/ articles/handbook/galda/.

Galda, L. \& Beach, R. Response to literature as a cultural activity. In R.B. Ruddell \& N.J. Unrau (Eds.), Theoretical models and processes of reading, 5th edition (pp. 852-869). Newark, DE: International Reading Association.

Galda, L. \& Cullinan, B.E. (2003). Literature and the child, 5th edition. CA: Wadsworth Group.

Grunbaum, J.A., Lowry, R., Kann, L., \& Pateman, B. (2000). Prevalence of health risk behaviors among Asian American/ Pacific Islander high school students. Journal of Adolescent Health, 27,(5), 322-330.

Harada, V. H. (1995). Issues of ethnicity, authenticity, and quality in Asian-American picture books, 1983-93. Youth Services in Libraries, 8, 135-149.

Heath, S.B. (1983). Ways with words: Language, life, and work in communities and classrooms. NY: Cambridge University Press.

Heller, C., Cunningham, B., Lee, G., \& Heller, H.M. (2000). Selecting children's picture books with positive Chinese, Japanese, and other Asian and Asian-American fathers and father figures. Multicultural Review, 9(4), 22-33.

Higgins, J.J. (2002). Multicultural children's literature: Creating and applying an evaluation tool in response to the needs of urban educators. New Horizons for Learning Online Journal, 8(1). Retrieved April 10, 2005, from http://www.new horizons.org/strategies/multicultural/higgins.htm

Howard, E.F. (1991). Authentic multicultural literature for children: An author's perspective. In Lindgren, M. (Ed.), The multicolored mirror: Cultural substance in literature for children and young adults. Fort Atkinson, Wisconsin.

Johnson, N. \& Giorgis, C. (2003/2003). Interview with the 2002 Newbery Medal winner, Linda Sue Park. Reading Teacher, 56(4), 394-398.

Karem, J. (2004). The romance of authenticity. VA: The University of Virginia Press.

Klein, M.E. A comparison of multicultural characters in the annotations of two recommended high school reading lists published thirty-one years apart. Unpublished master's thesis,
Kent State University, Ohio.

Le, T. (2002). Delinquency among Asian/Pacific Islanders: Review of literature and research. Justice Professional, 15, 57-70.

Lee, P. (n.d). Creating good multicultural literature: Challenges in publishing multicultural books. Asian-American Village. Retrieved December 11, 2003, from http://www.imdiversity. com/villages/asian/Article_Detail.asp?Article.

Lee, S. (2003) Model minorities and perpetual foreigners: The impact of stereotyping on Asian-American students. In Sadowski, M. (Ed.) Adolsecents at School: Perspectives on Youth, Identity, and Education. Cambridge, MA: Harvard Education Press.

Leung, C. (2003). Bicultural perspectives and reader response: Four American readers respond to Jean Fritz's Homesick. Canadian Modern Language Review. Retrieved December 6, 2005 from http://www.utpjournals.com/product/cmlr/601/ 601_leung.html.

Liang, C.T.H., Lee, S., \& Ting, M.P. (2002). Developing Asian American leaders. New Directions for Student Services, 97, 81-89.

Lindgren, M. (Ed.). (1991). The multicolored mirror: Cultural substance in literature for children and young adults. Fort Atkinson, Wisconsin

Louie, A. (1993). Growing up Asian-American: A look at some recent young adult novels. Journal of Youth Services in Libraries, 6, 115-127.

Lowery, R. M. (2003). Reading The Star Fisher. Multicultural Education, 10(3), 19-23.

Mehan, H.B. \& Robert, S.A. (2001). Thinking the nation: Representation of nations and the Pacific Rim in Latin American and Asian textbooks. Narrative Inquiry 11 (1), 195-215.

Mendoza, J \& Reese, D. (2001). Examining picture books for the early childhood classroom: Possibilities and pitfalls. Early Childhood Research and Practice 3, (2). Retrieved April 7, 2005, from http://ecrp.uiuc.edu/v3n2/mendoza.html.

Montecinos, C. (1994). Teachers of color and multiculturalism. Equity and Excellence In Education, 27,34-42.

Montecinos, C. (2004). Paradoxes in multicultural teacher education research: Students of color positioned as objects while ignored as subjects. International Journal of Qualitative Studies in Education, 17, 167-181.

Morgan, W. (1997). Critical literacy in the classroom: The art of the possible. New York: Routledge.

Mosely, J.J. Multicultural diversity of children's picture book: Robert Fulton Elementary School Library. Unpublished master's thesis, Kent State University, Ohio.

Nilsson, N. (2005). How does Hispanic portrayal in children's books measure up after 40 years? The answer is "It depends." The Reading Teacher, 58(6), 534-548.

Pang, V. O. (1995). Asian American children: A diverse population. In D.T. Nakanishi \& T.Y. Nishida (Eds.), Asian American educational experience (pp.167-179). New York, NY: Routledge.

Pang, V.O., Colvin, C., Tran, M., \& Barba,R.H. (1992). Beyond chopsticks and dragons: Selecting Asian-American literature for children. The Reading Teacher, 46(3), 216-224. 
Reimer, K.M. (1992). Multiethnic literature: Holding fast to dreams. Language Arts, 69(1), 14-21.

Rosenblatt, L. (2004). The transactional theory of reading and writing. In R.B. Ruddell \& N.J. Unrau (Eds.), Theoretical models and processes of reading, 5th edition (pp. 13631398). Newark, DE: International Reading Association.

Sadker, M., Sadker, D., \& Long, L. (1993). Gender and educational equality. In J.A. Banks \& C.A.M. Banks (Eds.), Multicultural education: Issues and perspectives (pp. 111128). Boston: Allyn \& Bacon.

Sautter, R.C. (2005, February). The serious business of children's books. The Society of Midland Authors: Literary License. Retrieved April 13, 2006, from http:// www.midlandauthors.com/newsletter/2_2005.html.

Say, A. (1991). Musings of a walking stereotype. School Library Journal, 37(12), 45-46.

Sheets, R.H. (2001). Trends in the scholarship of teachers of color for diverse populations: Implications for multicultural education. Equity and Excellence in Education, 34,26-31.

Short, K.G. \& Fox, D.L. (2003). The sociopolitical contexts of cultural authenticity. Ill: National Council of Teachers of English.

Slapin, B., Seale, D., \& Gonzales, R. (1992). How to tell the difference: A checklist. In B. Slapin \& D. Seale (Eds.), Through Indian eyes: The Native experience in books for children. Philadelphia, PA: New Society Publishers.

Sims, R. (1982). Shadow and substance. USA: National Council of Teachers of English.

Siu, S. (1996). Asian American students at risk: A literature review. (Report No. 8). U.S.: Center for Research on the Education of Students Placed At-Risk.

Temple, C.A., Martinez, M., Yokota, J. \& Naylor, A. (1998). Children's books in children's hands: An introduction to their literature. Boston: Allyn \& Bacon.

Tse, L. (1998). Seeing themselves through borrowed eyes. Multicultural Review, 7(2), 28-34.
U.S. Census Bureau (2000). Racial and ethnic classifications used in census 2000 and beyond. Retrieved May 5, 2005 from http://www.census.gov/population/www/socdemo/ race/racefactcb.html.

U.S. Census Bureau. (2002). The Asian population: 2000. Census 2002 Brief. U.S. Department of Commerce.

U.S. Census Bureau. (2003). Hispanic population reaches alltime high of 38.8 million, New census bureau estimates. Census Product Update. Retrieved May 5, 2005 from http:// www.census.gov/Press-Release/www/2003/cb03-100.html

Washington Office of the State Superintendent of Public Instruction. (1996, May). Washington models for the evaluation of bias content in instructional materials. Olympia, WA: No Author.

Willis-Rivera, J.L. \& Meeker, M. (2002). De que colores: A critical examination of multicultural children's books. Communication Education, 51, 269-279.

Yeh, C.J., Chen, J., Kwong, A., Chiang, L., Wang, Y., Pu-Folkes, F. (2002). Educators of Asian bilingual students: Pedagogical techniques, strategies, and challenges. Journal of Multilingual and Multicultural Development, 23(4), 296-315.

Yin, X. (2000). Chinese-American literature since the 1850s. Urbana and Chicago: University of Illinois Press.

\section{Cited Children's Literature}

Bishop, C. H. \& Wiese, K. (1938). The five Chinese brothers. New York: Penguin Putnam Books for Young Readers.

Kadohota, C. (2004). Kira-Kira. New York: Atheneum Press.

Lord, B.B. (1984). In the year of the boar and Jackie Robinson. New York: Harper \& Row.

Yep, L. (1991). The lost garden. New York: Beech Tree Paperback Book.

Young, E. (1995). Cat and rat: The legend of the Chinese zodiac. New York: Henry Holt and Company. 
